Gut and Liver, Vol. 9, No. 3, May 2015, pp. 411-416

\title{
Pyrrolidine Dithiocarbamate Inhibits Nuclear Factor kB and Toll-Like Receptor 4 Expression in Rats with Acute Necrotizing Pancreatitis
}

\author{
Min Xu, Kun-Ning Wang, Kai Wu, and Xing-Peng Wang \\ Department of Gastroenterology, Shanghai First People's Hospital, Shanghai JiaoTong University, Shanghai, China
}

Background/Aims: To investigate the expression of Tolllike receptor 4 (TLR4) in the pancreases of rats with acute necrotizing pancreatitis (ANP) and any changes upon treatment with pyrrolidine dithiocarbamate (PDTC), an inhibitor of nuclear factor $\kappa \mathrm{B}(\mathrm{NF}-\kappa \mathrm{B})$, as well as to determine the relationship between TLR4 and NF- $\kappa B$ in ANP pathogenesis. Methods: A total of 72 SD rats were randomly divided into three groups, namely, the control (sham-operation), ANP, and ANP with PDTC pretreatment groups. The PDTC-pretreated group was intraperitoneally injected with PDTC at a dose of $100 \mathrm{mg} / \mathrm{kg} 1$ hour before the induction of ANP. The expressions of TLR4 and NF- $\mathrm{KB}$ in pancreatic tissue were evaluated by immunohistochemistry and Western blot analysis. The mRNA levels of cytokines tumor necrosis factor $\alpha$, interleukin (IL)-1 $\beta$, and IL-6 were measured by reverse transcription polymerase chain reaction. Results: The expressions of TLR4, $\mathrm{NF}-\kappa \mathrm{B}$, and cytokine (NF- $\kappa \mathrm{B}$ target) genes in the pancreatic tissue increased more significantly in the ANP groups than in the sham-operation group at 3, 6, and 12 hours. Pretreatment with PDTC alleviated the inflammatory activation in the pancreas with ANP, causing a significant decrease in the expressions of TLR4, NF- $\kappa \mathrm{B}$, and cytokine genes in the pancreatic tissue. Conclusions: The expressions of TLR4 and NF$\kappa B$ were increased in the pancreases of rats with ANP. PDTC not only inhibits NF- $\mathrm{KB}$ but also suppresses the expression of TLR4 and downregulates the expression of the related cytokine genes. (Gut Liver 2015;9:411-416)

Key Words: Acute necrotizing pancreatitis; NF-kappa B; Tolllike receptor 4

\section{INTRODUCTION}

Acute pancreatitis is a common acute disease of high incidence; the mortality of acute necrotizing pancreatitis (ANP) could be as high as 30\%. ${ }^{1}$ Various researches have indicated that the activation of cytokines, such as tumor necrosis factor $\alpha$ (TNF- $\alpha$ ), interleukin (IL)- $1 \beta$ and IL-6, is closely related with the onset and progression of ANP. ${ }^{2}$ In addition, piled evidence has pointed out the involvement of Toll-like receptor 4 (TLR4) and nuclear factor $\kappa \mathrm{B}(\mathrm{NF}-\kappa \mathrm{B})$ in the activation of cytokines. Toll-like receptors (TLRs) are the only known trans-membrane proteins that transduce extracellular antigen recognition signals into cells and induce inflammation in mammals. ${ }^{3}$ TLR4 is the first identified TLR, and it can bind to many endogenous and exogenous ligands, ${ }^{4}$ thereby trigger the intracellular signaling pathways, activate $\mathrm{NF}-\kappa \mathrm{B}$ that regulates cytokine secretion, and as a result mediate inflammation.

The activation of $N F-\kappa B$ is critical to the development of ANP, and NF- $\kappa$ B probably regulates the onset of ANP. ${ }^{5} \mathrm{NF}-$ $\kappa \mathrm{B}$ is rapidly activated during pancreatitis. This activation may induce a self-defending genetic program before the onset of cellular injury, which might prevent higher degrees of damage of pancreatic acinar cells after secretagogue hyperstimulation. ${ }^{6} \mathrm{NF}-$ $\kappa \mathrm{B}$ was also activated in peritoneal and alveolar macrophages after taurocholate pancreatitis induction. ${ }^{7}$ The global inflammation in ANP is one important step to initiate multiorgan dysfunction syndrome, in which NF- $\kappa \mathrm{B}$ functions as a 'messenger." During onset stage of ANP, through NF- $\mathrm{B}$, local inflammation mediates the activation of various inflammatory factors, which in turn spread to other organs and lead to inflammation of multiple organs. ${ }^{9}$

Pyrrolidine dithiocarbamate (PDTC) was reported to be able to attenuate experimental acute pancreatitis. ${ }^{7,10}$ Prevention of the activation of NF- $\kappa$ B by PDTC ameliorates the tissue injury

Correspondence to: $\mathrm{Min} \mathrm{Xu}$

Department of Gastroenterology, Shanghai First People’s Hospital, Shanghai JiaoTong University, Shanghai 200080, China

Tel: +86-13386259716, E-mail: xumin73@126.com

Received on February 13, 2014. Revised on April 24, 2014. Accepted on May 20, 2014. Published online on October 7, 2014 pISSN 1976-2283 eISSN 2005-1212 http://dx.doi.org/10.5009/gnl14050

(a) This is an Open Access article distributed under the terms of the Creative Commons Attribution Non-Commercial License (http://creativecommons.org/licenses/by-nc/3.0) which permits unrestricted non-commercial use, distribution, and reproduction in any medium, provided the original work is properly cited. 
associated with experimental murine acute pancreatitis. PDTC treatment can attenuate the degree of pancreas and lung injury, upregulation/expression of intracellular adhesion molecule-1, staining for nitrotyrosine, and lipid peroxidation. ${ }^{10}$ Another study reported that pretreatment with PDTC dose-dependently attenuated the NF- $\kappa \mathrm{B}$ activation and improved the survival of the rats, although it did not affect the early increase in serum amylase and histological findings. ${ }^{7}$ In this study, we investigated the expression of TLR4 in pancreas of rats with ANP, and compared TLR4 expression in pancreas with and without NF- $\mathrm{B}$ inhibitor PDTC.

\section{MATERIALS AND METHODS}

\section{Materials}

TLR4 antibody and NF- $\kappa$ B antibody (Boster, Wuhan, China), NF- $\mathrm{B}$ p65 antibody (Ebioscience, USA), BCA protein concentration Kit (Pierce, USA), reverse transcription polymerase chain reaction (RT-PCR) Kit (Gibco, USA), TRIzol (Invitrogen, USA), PCR primer and DNA ladder (Sbsgene, China).

\section{Animal grouping and ANP model development}

Seventy two male SD rats were divided into three groups with 24 rats each as sham-operation, ANP, and ANP with PDTC pretreatment. Under pentobarbital anesthesia $(50 \mathrm{mg} / \mathrm{kg}$ body weight), a laparotomy was performed and 5\% sodium taurocholate in distilled water ( $1 \mathrm{~mL} / \mathrm{kg}$ body weight) was injected into the biliopancreatic duct at a rate of $0.2 \mathrm{~mL} / \mathrm{min}$ by a microinfusion pump. Controls received an intraductal infusion of saline (0.2 $\mathrm{mL} / \mathrm{min}){ }^{11}$ Rats were sacrificed at 3, 6, and 12 hours after the operation (eight animals at each time point). A total of $5 \mathrm{~mL}$ blood was gained from abdominal aorta and after 2 hours serum was isolated at 3,000 rpm for detection of IL-1 $\beta$, IL-6, and $\mathrm{TNF} \alpha$. The head of pancreas, consistent in pathologic changes in this ANP model, was taken and divided into two parts for pathology examination and immune biochemistry respectively. The tail of pancreas was also collected and stored in liquid nitrogen.

\section{Pathology examination}

The collected pancreas was fixed in 10\% formaldehyde. The following procedures including dehydration, bedding, paraffin sectioning, and hematoxylin and eosin staining were performed as previously described. Those sections were further analyzed by pathologists.

\section{Immunobiochemistry}

The routine streptavidin-perosidase method was utilized for immunobiochemistry staining. The primary antibodies (rabbit anti-rat TLR/NF- $\kappa$ B monoclonal antibody) were diluted at 1:40. Phosphate-buffered saline was used in place of the primary antibody as negative control. Cells with brown staining in the cytosol were considered positive for TLR4/NF- $\kappa \mathrm{B}$ expression. Five different areas were examined for each section, and the TLR4/NF- $\kappa \mathrm{B}$ positive cell number as well as the total cell number were counted. The positive rate was calculated as positive rate $=\mathrm{TLR} 4 / \mathrm{NF}-\kappa \mathrm{B}-$ positive cell number/total cell number $\times 100 \%$.

\section{Western blotting}

Fifty mg of liquid nitrogen frozen pancreas was digested in extraction buffer, vortex well, and the supernatant was separated by centrifuge. The protein concentration was determined with BCA protein assay kit. Thirty $\mu \mathrm{g}$ protein was loaded for each lane. The blot was incubated with primary antibodies (rabbit anti-rat TLR4 antibody at 1:50 dilution, rabbit anti-rat NF- $\kappa \mathrm{B}$ p65 subunit at 1:1,000 dilution) overnight at $4^{\circ} \mathrm{C}$, and then was incubated with secondary antibody (sheep anti-rabbit HRP at 1:1,000 dilution) for 1 hour at room temperature. The band was developed with enhanced chemiluminescence and the strength of each band was quantified with Fluor-S-Multi Imager software.

\section{Semi-quantitative RT-PCR}

Total RNA was extracted from pancreas with TRIzol and 4 $\mu \mathrm{g}$ total RNA was used for first-strand cDNA synthesis. RT-PCR was performed and ultraviolet development of electrophoresis image and analysis of the band strength with band-scan5.0 software. The primers of targeted genes were shown in Table 1.

\section{Statistical analysis}

The result is represented with $\chi \pm \mathrm{s}$. SAS 6.12 (SAS Institute, Cary, NC, USA) was used for all the analysis. Intragroup data was analyzed with analysis of variance, and the paired data was analyzed with t test. The result is considered statistically signifi-

Table 1. Primer Sequences of Target Genes

\begin{tabular}{clccc}
\hline $\begin{array}{c}\text { Target } \\
\text { gene }\end{array}$ & \multicolumn{1}{c}{ Primer sequence } & $\begin{array}{c}\text { TM, } \\
{ }^{\circ} \mathrm{C}\end{array}$ & $\begin{array}{c}\text { Cycle } \\
\text { no. }\end{array}$ & $\begin{array}{c}\text { Product } \\
\text { size, bp }\end{array}$ \\
\hline TNF- $\alpha$ & 5'cac cacgctcttctgtct act gaa c3' $^{\prime}$ & 58 & 35 & 546 \\
IL-1 $\beta$ & 5'ccg gactccgtgatgtctaagtac t3' & & & \\
& 5'ata gcagct ttc gacagt gag3' & 53 & 35 & 748 \\
IL-6 & 5'gtcaac tat gtcccgacc att3' & & & \\
& 5'gag aaagagttgtgcaatgg c3' & 62 & 40 & 444 \\
& 5'act aggtttgcc gag tag acc 3' & & & \\
GADPH & 5'cat gccagt gag ctt ccc gtt 3' & 56 & 28 & 408 \\
& 5'gtg gag tct act ggcgtcttc 3' & & & \\
\hline
\end{tabular}

TNF- $\alpha$, tumor necrosis factor $\alpha$; IL, interleukin. 
cant if $\mathrm{p}<0.05$.

\section{RESULTS}

\section{The development of rat ANP model and the evaluation of PDTC treatment}

Pathology examination showed that the pancreases of ANP rats were swollen. The lobe intervals, small lobe intervals and pancreatic acinar intervals were widened, and the blood vessels dilatation and congestion were observed. In addition, the acinar necrosis was flake-like, and a large amount of monocytes and neutrophils were seen in necrotic areas and around the vessels. All of these evidence confirmed the success of the rat ANP model development. In contrast, the inflammation response in pancreas of the ANP pretreated with PDTC was alleviated compared to ANP counterparts, the swollen symptom was mitigated, and the acinar necrosis and inflammatic cells were reduced as well (Table 2).

\section{The expression change of TLR4 and NF-KB in pancreas}

The immunobiochemistry results indicated that TLR4 expression in rat pancreas was mainly from vascular system, while there was no TLR4 expression in acinar cells. TLR4 positive rate was significantly higher in ANP than in ANP with PDTC treatment and sham-operation group (Table 3, Fig. 1). In shamoperation controls, NF- $\mathrm{k}$ expression was almost depleted from acinar cell nucleus and only seen in a few acinar cell cytosol. But in ANP group, strong $\mathrm{NF}-\kappa \mathrm{B}$ expression were detected in both acinar cell nucleus and cytosol, while in PDTC pretreated ANP group, NF- $\kappa \mathrm{B}$ positive rate is much lower than that in ANP group (Table 4, Fig. 2).

Western blotting result revealed the expression level of TLR4 and $\mathrm{NF}-\kappa \mathrm{B}$ in pancreas at 3, 6, and 12 hours time point from ANP and ANP with PDTC pretreatment group. Expression level of both proteins was also shown for sham-operation control group (Fig. 3). Compared with sham-operation control, ANP group showed significant higher expression level for pancreatic TLR4 at every time point. TLR4 expression is much lower in PDTC pretreated ANP group. Furthermore, NF- $\kappa \mathrm{B}$ expression level was also significantly increased in ANP group in comparison with sham-operation control, while PDTC pretreated ANP group showed a little lower NF- $\mathrm{KB}$ expression than that in ANP group. These results suggested that while the expression of TLR4 and NF- $\kappa \mathrm{B}$ significantly increased in ANP rat pancreas, PDTC

Table 2. Schmidt Evaluation of the Effectiveness of Pyrrolidine Dithiocarbamate in Tissue (U/L, mean \pm SD)

\begin{tabular}{|c|c|c|c|c|c|c|}
\hline Group & Time, hr & No. & Edema & Hemorrhage & Necrosis & Leukocyte infiltration \\
\hline \multirow[t]{3}{*}{ Control } & 3 & 8 & $0.93 \pm 0.18$ & $0.49 \pm 0.13$ & $0.14 \pm 0.06$ & $0.15 \pm 0.07$ \\
\hline & 6 & 8 & $1.08 \pm 0.20$ & $0.72 \pm 0.21$ & $0.37 \pm 0.09$ & $0.17 \pm 0.04$ \\
\hline & 12 & 8 & $0.78 \pm 0.15$ & $0.43 \pm 0.17$ & $0.56 \pm 0.12$ & $0.21 \pm 0.09$ \\
\hline \multirow[t]{3}{*}{ ANP } & 3 & 8 & $2.50 \pm 0.19^{*}$ & $2.31 \pm 0.16^{*}$ & $2.31 \pm 0.23^{*}$ & $1.94 \pm 0.33^{*}$ \\
\hline & 6 & 8 & $3.00 \pm 0.21^{*}$ & $2.50 \pm 0.37^{*}$ & $2.89 \pm 0.26^{*}$ & $2.39 \pm 0.35^{*}$ \\
\hline & 12 & 8 & $3.61 \pm 0.16^{*}$ & $2.72 \pm 0.25^{*}$ & $3.44 \pm 0.11^{*}$ & $3.13 \pm 0.18^{*}$ \\
\hline \multirow[t]{3}{*}{ PDTC treatment } & 3 & 8 & $1.58 \pm 0.15^{\ddagger}$ & $1.75 \pm 0.21^{\dagger}$ & $1.58 \pm 0.24^{\dagger}$ & $1.50 \pm 0.26^{\dagger}$ \\
\hline & 6 & 8 & $2.33 \pm 0.17^{\dagger}$ & $2.00 \pm 0.32^{\dagger}$ & $1.92 \pm 0.27^{\dagger}$ & $1.42 \pm 0.20^{\ddagger}$ \\
\hline & 12 & 8 & $2.08 \pm 0.20^{\ddagger}$ & $0.67 \pm 0.11^{\ddagger}$ & $1.25 \pm 0.21^{\ddagger}$ & $0.92 \pm 0.15^{\ddagger}$ \\
\hline
\end{tabular}

ANP, acute necrotizing pancreatitis; PDTC, pyrrolidine dithiocarbamate.

${ }^{*} \mathrm{p}<0.01$, compared with the control group; ${ }^{\dagger} \mathrm{p}<0.05,{ }^{\ddagger} \mathrm{p}<0.01$, compared with the ANP group.

Table 3. Rate of Toll-Like Receptor 4 Positivity in the Pancreas at Different Time Points $\left(\%\right.$, mean $_{ \pm}$SD)

\begin{tabular}{lccc}
\hline & 3 Hours $(\mathrm{n}=8)$ & 6 Hours $(\mathrm{n}=8)$ & 12 Hours $(\mathrm{n}=8)$ \\
\hline Sham-operation & $4.03 \pm 0.81$ & $4.27 \pm 0.52$ & $4.38 \pm 0.76$ \\
ANP & $23.56 \pm 4.01^{*}$ & $39.68 \pm 3.34^{*}$ & $45.81 \pm 9.68^{*}$ \\
ANP with PDTC & $6.68 \pm 0.71^{\ddagger}$ & $17.47 \pm 1.02^{\ddagger}$ & $19.51 \pm 4.98^{\dagger}$ \\
pretreatment & & & \\
\hline
\end{tabular}

ANP, acute necrotizing pancreatitis; PDTC, pyrrolidine dithiocarbamate.

${ }^{*} \mathrm{p}<0.01$, compared with the sham-operation group; ${ }^{\dagger} \mathrm{p}<0.05,{ }^{\ddagger} \mathrm{p}<0.01$, compared with the ANP group.
Table 4. Rate of Nuclear Factor $\kappa \mathrm{B}$ Positivity in the Pancreas at Different Time Points $\left(\%\right.$, mean $\left._{ \pm} \mathrm{SD}\right)$

\begin{tabular}{lccc}
\hline & 3 Hours $(\mathrm{n}=8)$ & 6 Hours $(\mathrm{n}=8)$ & 12 Hours $(\mathrm{n}=8)$ \\
\hline Sham-operation & $2.11 \pm 0.26$ & $2.17 \pm 0.18$ & $2.35 \pm 0.31$ \\
ANP & $13.62 \pm 1.32^{*}$ & $24.52 \pm 3.45^{*}$ & $38.99 \pm 5.76^{*}$ \\
ANP with PDTC & $7.45 \pm 1.01^{\dagger}$ & $11.09 \pm 1.27^{\dagger}$ & $8.71 \pm 1.18^{\dagger}$ \\
pretreatment & & & \\
\hline
\end{tabular}

ANP, acute necrotizing pancreatitis; PDTC, pyrrolidine dithiocarbamate.

${ }^{*} \mathrm{p}<0.01$, compared with the sham-operation group; ${ }^{\dagger} \mathrm{p}<0.01$, compared with the ANP group. 

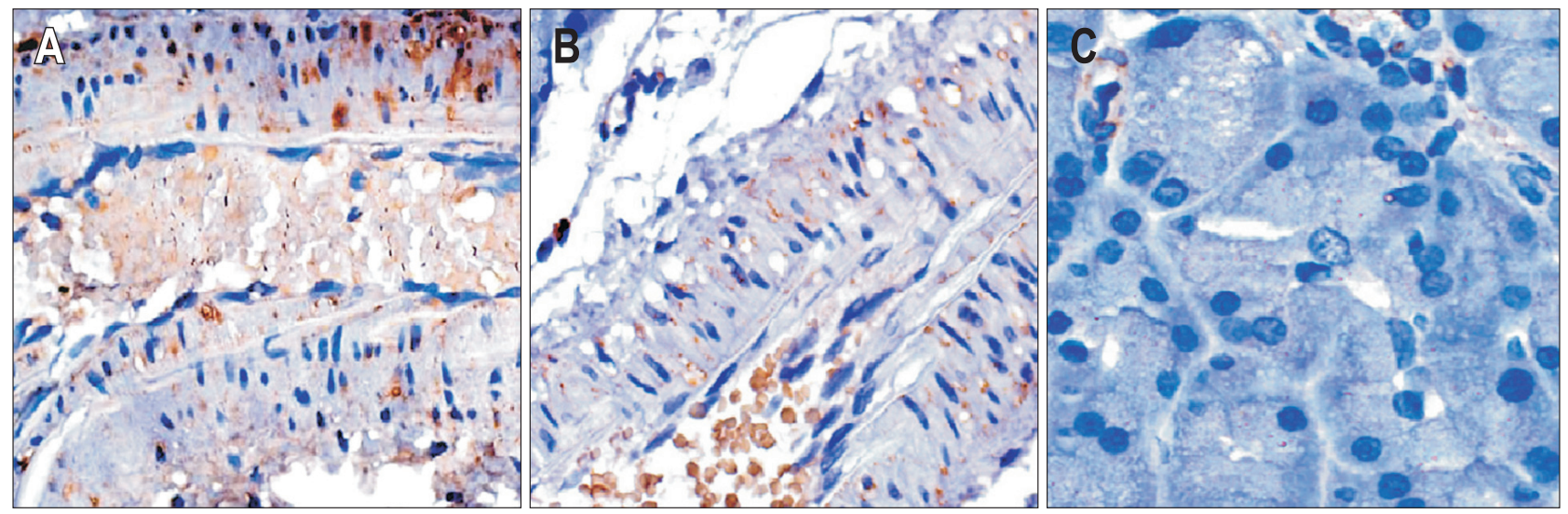

Fig. 1. Toll-like receptor 4 expression in the pancreatic vascular endothelial cells. (A) Acute necrotizing pancreatitis (ANP) group, (B) ANP with pyrrolidine dithiocarbamate pretreatment group, and (C) sham-operation control group (A and B, H\&E stain, $\times 200$; C, H\&E stain, $\times 400$ ).
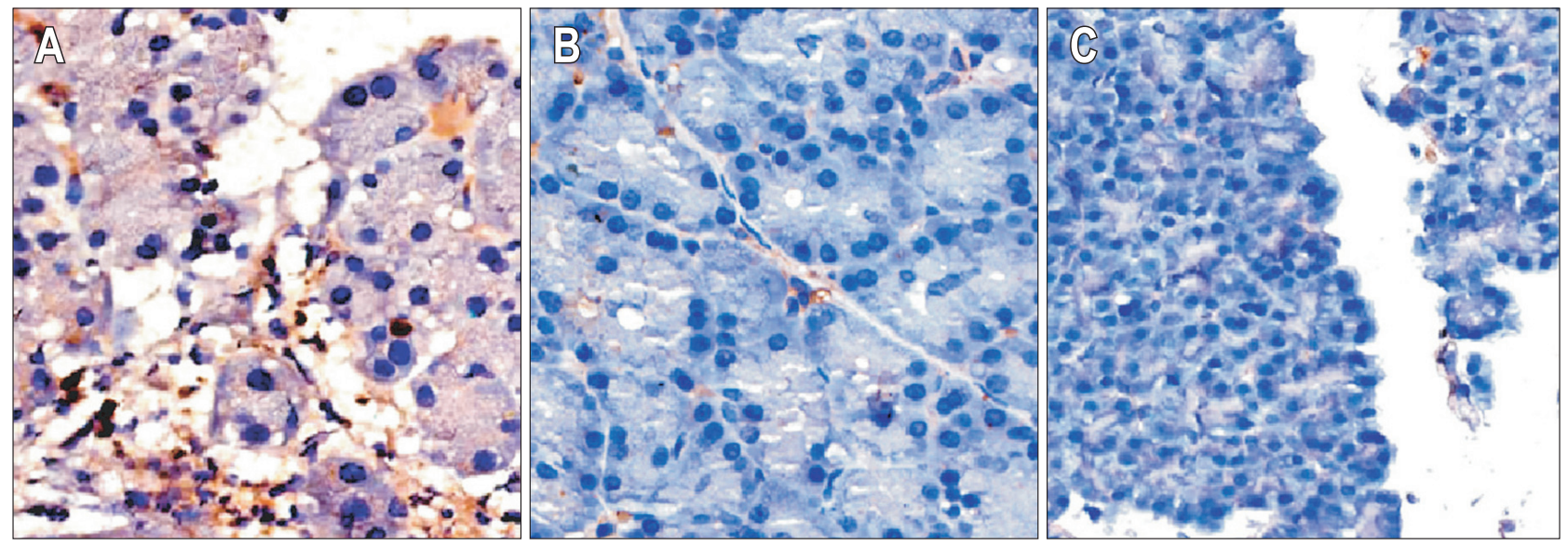

Fig. 2. Nuclear factor $\kappa \mathrm{B}$ expression in the pancreas. (A) Acute necrotizing pancreatitis (ANP) group, (B) ANP with pyrrolidine dithiocarbamate pretreatment group, and (C) sham-operation control group (A, B, and C, H\&E stain, $\times 200$ ).

could downregulate TLR4 expression and inhibit NF- $\kappa \mathrm{B}$ expression in ANP rat pancreas.

\section{Pancreatic cytokines mRNA expression change}

Electrophoresis of semi-quantitative RT-PCR result was shown in Fig. 4. In ANP rat group, TNF- $\alpha$ and IL- 6 were higher at 3 hours than at 6 hours or 12 hours at mRNA level $(p<0.05)$, while mRNA expression level of IL-1 $\beta$ was much higher at 12 hours than at 3 hours or 6 hours $(\mathrm{p}<0.05)$. In PDTC pretreated ANP group, mRNA of TNF- $\alpha$, IL- $1 \beta$, and IL- 6 were all expressed at a decreased level compared with that in ANP group. A closer examination revealed that in comparison with ANP group, TNF- $\alpha$ mRNA level was significantly lower in PDTC pretreated group at 6 hours time point $(\mathrm{p}<0.05)$, IL-1 $\beta$ mRNA expression was obviously lower at 6 hours and 12 hours time points $(\mathrm{p}<0.05)$, and IL-6 mRNA expression was lower at 3 hours time point $(\mathrm{p}<0.05)$.

\section{DISCUSSION}

In this study, we observed the expression of TLR4 and NF- $\kappa B$ in pancreas from ANP rat and PDTC (a NF- $\mathrm{B}$ inhibitor) pretreated ANP rat. We checked mRNA levels of several cytokines such as TNF- $\alpha$, IL-1 $\beta$, and IL-6 in pancreas as well. Our results demonstrated that comparing with that in sham-operation rats, TLR4 and NF- $\kappa$ B showed significantly increased expression level in ANP rat pancreas, while PDTC pretreatment inhibited $N F-\kappa B$ expression in ANP rat pancreas and downregulated TLR4 protein level as well as some cytokines, such as TNF- $\alpha, \mathrm{IL}-1 \beta$, and IL-6, at mRNA level. All of these observations suggested that inhibition of $N F-\kappa B$ might be one of the mechanisms contributing to PDTC's function of alleviating the pathology symptoms in ANP.

Our data was in accordance with the previous findings that PDTC can alleviate inflammation through inhibiting NF- $\mathrm{KB}$, and further confirmed that TLR4 is expressed in pancreas of acute pancreatitis rats. ${ }^{12}$ In this study, we also observed that the 

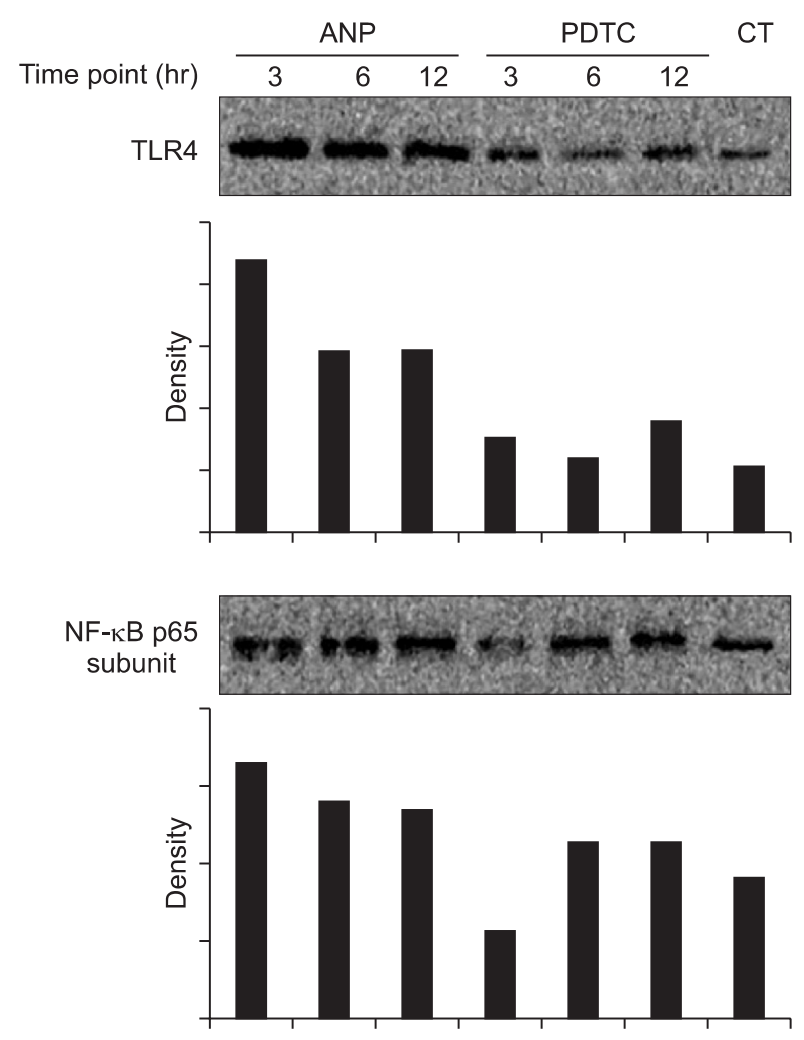

Actin

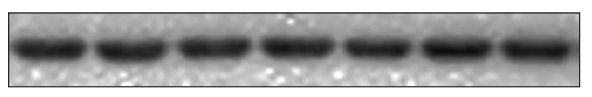

Fig. 3. Western blots of Toll-like receptor 4 (TLR4) and nuclear factor $\kappa \mathrm{B}(\mathrm{NF}-\kappa \mathrm{B})$. The expression of both TLR4 and NF- $\kappa \mathrm{B}$ was checked at 3-, 6-, and 12-hour time points in the pancreas of rats in the acute necrotizing pancreatitis (ANP) and pyrrolidine dithiocarbamate (PDTC) pretreated ANP groups. TLR4 and NF- $\kappa$ B expression in the shamoperated rat pancreases is also shown as controls.

expression of TLR4 decreased in PDTC pretreated ANP rats. The reason that TLR4 is downregulated by PDTC remains unclear. There are three possibilities to address the decreasing of TLR4 expression. First, PDTC could inhibit TLR4 expression by itself. Secondly, NF-кB or some inflammatory factors downstream of NF- $\mathrm{KB}$ in endotoxin signaling pathway could have positive feedback on TLR4, e.g., when NF- $\mathrm{kB}$ and therefore the downstream inflammatory factors are inhibited by PDTC, so is their positive feedback on TLR4. Thus, TLR4 is downregulated as well. Lastly, some anti-inflammatory factors downstream of NF- $\mathrm{kB}$ in endotoxin signaling pathway could have negative feedback on TLR4 expression. So when NF- $\kappa$ B is inhibited by PDTC, the antiinflammatory factors may increase and their negative feedback on TLR4 may also increase, thus lead to the decrease of TLR4 expression.

A lot of efforts have been put into understanding the relationship between TLR4 and NF- $\mathrm{KB}$. TLR4 signaling path way is similar to that of a NF- $\kappa B$ activator: IL-1 and signaling pathways regulated by TLR4 or TNF- $\alpha$ could activate NF- $\kappa \mathrm{B} .{ }^{13}$ Those activations required the involvement of TRIP6, TRAF2,

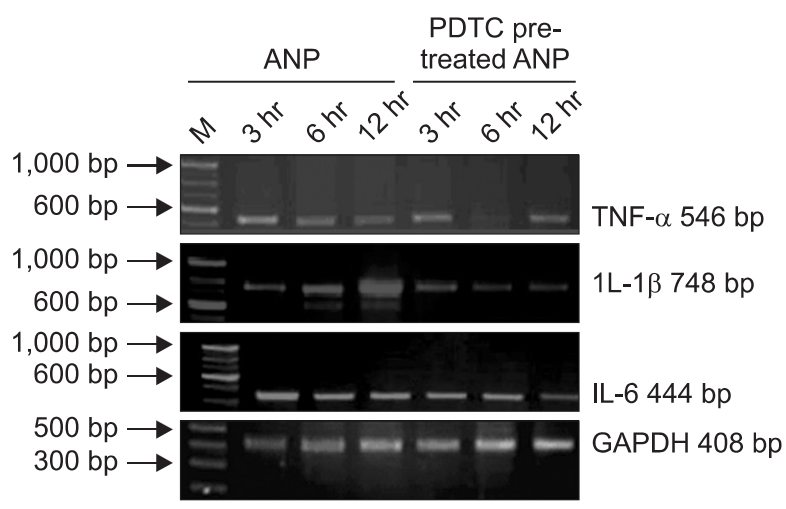

Fig. 4. Electrophoresis of reverse transcription polymerase chain reaction results of the tumor necrosis factor $\alpha$ (TNF- $\alpha$ ), interleukin (IL)-1 $\beta$, and IL- 6 mRNA in the rat pancreas.

ANP, acute necrotizing pancreatitis; PDTC, pyrrolidine dithiocarbamate.

TRAF6, MyD88, TLR interacting proteins, and IL-1 receptor related enzyme $1 .{ }^{14}$ There are pathways other than TLR4 signaling pathway, such as IL- 1 and TNF- $\alpha$ pathways, could activate NF$\kappa \mathrm{B}$. Those pathways are involved in some complicated networks comprising of a lot of other factors and regulate each other. These new findings paves a new avenue of studying ANP so that we could identify new targets to cure ANP, which is of great importance to both acute pancreatitis related clinical application and basic mechanism research on ANP models.

\section{CONFLICTS OF INTEREST}

No potential conflict of interest relevant to this article was reported

\section{REFERENCES}

1. Algül H, Tando Y, Schneider G, Weidenbach H, Adler G, Schmid RM. Acute experimental pancreatitis and NF-kappaB/Rel activation. Pancreatology 2002;2:503-509.

2. Liu HS, Pan CE, Liu QG, Yang W, Liu XM. Effect of NF-kappaB and p38 MAPK in activated monocytes/macrophages on proinflammatory cytokines of rats with acute pancreatitis. World J Gastroenterol 2003;9:2513-2518.

3. Gordon S. Pattern recognition receptors: doubling up for the innate immune response. Cell 2002;111:927-930.

4. Johnson GB, Brunn GJ, Platt JL. Cutting edge: an endogenous pathway to systemic inflammatory response syndrome (SIRS)-like reactions through Toll-like receptor 4. J Immunol 2004;172:20-24.

5. Huang H, Liu Y, Daniluk J, et al. Activation of nuclear factor-kap$\mathrm{paB}$ in acinar cells increases the severity of pancreatitis in mice. Gastroenterology 2013;144:202-210.

6. Steinle AU, Weidenbach H, Wagner M, Adler G, Schmid RM. NFkappaB/Rel activation in cerulein pancreatitis. Gastroenterology 1999;116:420-430. 
7. Satoh A, Shimosegawa T, Fujita M, et al. Inhibition of nuclear factor-kappaB activation improves the survival of rats with taurocholate pancreatitis. Gut 1999;44:253-258.

8. Giakoustidis A, Mudan SS, Giakoustidis D. Dissecting the stress activating signaling pathways in acute pancreatitis. Hepatogastroenterology 2010;57:653-656.

9. Sah RP, Garg P, Saluja AK. Pathogenic mechanisms of acute pancreatitis. Curr Opin Gastroenterol 2012;28:507-515.

10. Virlos I, Mazzon E, Serraino I, et al. Pyrrolidine dithiocarbamate reduces the severity of cerulein-induced murine acute pancreatitis. Shock 2003;20:544-550.

11. Aho HJ, Koskensalo SM, Nevalainen TJ. Experimental pancreatitis in the rat. Sodium taurocholate-induced acute haemorrhagic pancreatitis. Scand J Gastroenterol 1980;15:411-416.

12. Li Y, Zhou ZG, Xia QJ, et al. Toll-like receptor 4 detected in exocrine pancreas and the change of expression in cerulein-induced pancreatitis. Pancreas 2005;30:375-381.

13. Magder S, Neculcea J, Neculcea V, Sladek R. Lipopolysaccharide and TNF-alpha produce very similar changes in gene expression in human endothelial cells. J Vasc Res 2006;43:447-461.

14. Li L, Bin LH, Li F, et al. TRIP6 is a RIP2-associated common signaling component of multiple NF-kappaB activation pathways. J Cell Sci 2005;118(Pt 3):555-563. 